\title{
Real Picture of the World During COVID-19 Pandemic: Mental Health Matters
}

\author{
Rakhi Gupta \\ Jaipur National University, Jaipur, Rajasthan,India.
}

\section{ABSTRACT}

The present study focuses on the dangerous disease 'Coronavirus', which ruined the peaceful life of the universe. It started in the period from 2020 to 2021 and forced humans to think- "where they went wrong 'and asked the question to himself/herself "is nature taking its revenge?". The study aim is to portray the real grief, painful and horrific picture of the Universe- Developing countries like India and South African recording each day multiple new cases of Coronavirus, including the number of deaths climbing day by day. The group of survival is also undergoing a constant mental health problem. As the constant news of Coronavirus has plunged the world and disturbed each mental health especially youth who are experiencing a 'cage world' Thus, this study's main aim is not only to focus on the solution to the invisible pain but also will reveal the dark side of the young generation's mental health which is known as depression, anxiety, suppression, and ultimately how it takes its road into a horrific result as anorexia, insomnia, bipolar disorder, dementia, and suicide. The covid-19 situation has brought more complexities into the mind of adolescence and teenhood especially when they are confronting societal, personal, and educational issues. The major concern comes when a child suffers from the loss of childhood innocence during the pandemic and finds no space of their own due to parents' stressful relationship or having a terrible experience of losing both of their parents or close family member due to Covid disease. Moreover, asking for financial and emotional help in times of need became tough, and last but not least issue is a sharp rise in poverty when the covid-19 pandemic led to a strict nationwide lockdown and most of the youth are suffering from the loss of hope for any work opportunity.

\section{KEY WORDS: COVID-19, DEPRESSION, CONFESSION, POVERTY, MENTAL TRAUMA.}

\section{INTRODUCTION}

Coronavirus pandemic situation has risen the significance of new word- 'Loss'. A sense of loss towards the world of Hope- Hope for a new opportunity, secure life, peaceful mind, re-opening of educational institutions, jobs or innovative opportunities, and survival. Coronavirus disease like a winter disrupted lives all around the world. Still, as a human, we should never forget that - If Winter comes, can Spring be far behind? (Shelley, 20)- there is always room for optimism (Brundha et al., 2019).

The Evolution of Coronavirus Disease in form of KAAL and The Horror Reality of 'The Disease': A novel coronavirus

Biosc Biotech Res Comm P-ISSN: 0974-6455 E-ISSN: 2321-4007

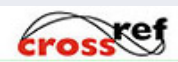

Identifiers and Pagination

Year: 2021 Vol: 14 No (9) Special Issue

Pages: 259-261

This is an open access article under Creative

Commons License Attribn 4.0 Intl (CC-BY).

DOI: http://dx.doi.org/10.21786/bbrc/14.9.48 furst identified in Wuhan, China (2019). It is a transmissive disease which first came from animals and converted into a form of viral and spread it to human. In an interview with Fox News on Feb. 16, Sen. Tom Cotton, R-Ark., suggested that the coronavirus may have come from a virology laboratory in Wuhan, China, where the outbreak emerged. After this, there were numerous suggestions and supposition came up about the origin of "Coronavirus 'disease. This disease another name can be considered as a zoonotic disease. Zoonotic diseases are caused by harmful germs like viruses, parasites, and fungus, and eating notveg can also be the major reason for the origin of the disease. Sometimes animal appears clean and healthy, but it can be covered with multiple germs.

Thus, safe consumption is important, if a human wants a happy and healthy long life. The World Health Organization has also given its report and pieces of evidence about the causing of several diseases due to the consumption of non-veg food. Though it was also being noted that well-cooked food is more secure and safe enough compare to eating raw meat.

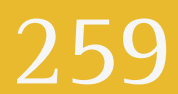


According to the news report, countries like India and Italy did not release the actual figure of death of patients and hiding about the lack of oxygen facilities, ventilators, and ICU beds, especially when the second weave hit many of the developing countries. India Today reported '4,01993'- the number of new Covid cases in 2021, which was also based on the official figure- as several cities ground report indicates that the official number of death count is an understatement (Carey et al., 1996).

The question is not 'Who is accountable for the origin of Covid but How to find a perfect solution to fight against it: From the year 2020 to 2021, World has experienced enough about the number of infections that keep soaring around it swiftly and put each life as tumultuous. The American existential psychiatrist Irvin David Yalom, once stated in his well-known book entitled- Staring at the Sun: Overcoming the Terror of Death (2009) - "The more unlived your life, the greater your death anxiety. The more you fail to experience your life fully, the more you will fear death" (Lassale et al., 2019).

Coronavirus is an infectious disease that spread its symptoms from person to person. It causes respiratory illness in human, when an infected person cough, sneezes or stand next to you (within six feet) and smells, it can spread this disease easily. Even it lingers in the air for hours, no matters if an infected person has left the space or not especially in an enclosed place with poor ventilation. This is the major reason for an immediate reaction to mental health. Transmission of the disease forced humans to remain within four walls alone. Followings are the statement of some common people, which depicts their painful isolated situation and their desire to meet their close family member: -

Eighty-year-old Thresia, a native of Kerala's Pathanamthitta district, couldn't hold back her tears when she spoke about her little sister, Achamma, who is 75 years old. Achamma was living with a domestic worker in one of the villages in Pathanamthitta until her son took her with him to Ireland a few months ago. "I would visit her frequently or she would come to meet me as we lived within a radius of 10 to 12 kilometers. Because of the lockdown, I could not meet my sister for a long time. Once it was lifted, we were able to meet each other and I was happy. However, her son took her to Ireland with him as he did not want his elderly mother to live alone during the pandemic, although she never wanted to leave her house. Now, I heard that she is not well, which means, I won't be able to meet her again. This pandemic won't end, and we can never meet," says Thresia as weeps. It has been about five months since she last met her sister. (The News Minute, 12)

(2020-21) Lockdown has also witnessed an increasing number of cases in the domestic violence issues. Due to current pandemic situation, each individual is not only suffering from the idea of close-experiences of death, isolation, social-distancing, and various other restriction but the statics also shows that families who are living together have been suffering from the idea of stress relationship between husband and wife, which ultimately leading towards divorce. The major reason for the separation of the married couple are -living together for a long period in a close confined space, It also causes lack of interest between each-other and creates monotonous relationships, financial issues, when one of the spouses find themselves out of job- this creates a lot of stress within the relationship and various violent argument about financial decision confronted by the couples. Apart from this, financial infidelity, hidden financial decisions, secret purchase, gambling addiction, division of household labor such as household duties, children duties do also play an integral role in separation between a pure relationship like husband-wife.

The concept of a quarantine imposed on children and youth to confine them within four walls because of subsequent closure of schools and colleges. Teens are waiting desperately for a normal life routine. The effect of lockdown attacking directly on their mental health and their pleasurable life. More than $65 \%$ of kids have become technology device addicted. They are unable to stay away from their mobile. Virtual tutoring increased this habit in kid's daily life. As a result, they are facing not only physical but mental problems such as lack of sleep, daytime tiredness, headache, annoying nature, weight gain, not interested in any outside games activities, and uncontrolled anger. College students are experiencing both family financial stresses and their parent's strained relationship (Ravichandran \&t Brundha 2016).

Lockdown made some of the teens' life as hell as a consequence of increment of stress and frustration- either they are leaving their education or forcing themselves towards child labor due to pandemics. Parents are involved in their problems that they have forgotten about their child's abnormal behavioral stage. Moreover, the second wave of covid-19 have devastated some families and left the youth without any guardians and some parents lost their child: - "Among them is the Gregory family of Meerut, who lost twin sons Joefred and Alfred to coronavirus. The twins had turned 24 a day before they were tested positive for the virus."Our family is broken. We are only three in the family now," lamented the twins' Father Gregory Rafael, adding that his sons Joefred Varghese GrAlfrednd Ralfred George Gregory died due to Covid." (Business Today)

Psychological Health: According to the above-mention reason and real facts shows that pandemic increases not only the number of death but also the number of mental health patients. If no direction has been given to them, they can risk their life too. At present, we are living in world of fear of death, self-protection or close family member's safety and above all the stage of isolation makes it worse. As Gautama Buddha stated-: "Your worst enemy cannot hurt you as much as your own thoughts, when you haven't mastered them". (204) Finding out the solution to restoring calm and peace in a chaotic world considers as a tough task in the present time. Inner peace amid negative environment, especially when electronic device or TV and social media apps like 
Facebook, WhatsApp and many more has become a major part of our life (Shreya \&t Brundha 2016).

It helps to spread the number of pseudo-news and gives a slow poison to our belief system. Obsessed people to it, incline towards delusion world and diminishes all kind of self-control and discipline of life. Untrue stories mislead people and increase the rate of fear, anxiety, and paranoia- which are also known as a symbol of mental illness. Covid-19 has killed the traditional work environment, similarly, it has taken away child pleasurable and memorable school moments due to the closure of schools and has risen stress levels in each human mind. Families, who are not able to cover the mortgage, car lease, kid's study loan and it increased the number of unemployment, people have lost jobs due to pandemic and deep poverty especially when you are self-isolated. Among all these situations, how can even one advise to remain peaceful? But Peace of mind is an essential tool (Samadarshi et al., 2020).

Most people are suffering from adverse times and they commit suicide, but 'SUICIDE' is not the last solution. Better to self-harming, one should ask for help, speak openly and bravely about their stress and have faith in the word 'HOPE'. As it is truly said- "Where there is a will there is a way" (Kael, 141). Further added this line with English romantic poet P.B Shelley's well-known poemOde to the West Wind (1819)- - If Winter comes, can Spring be far behind? (Shelley, 20)- BEING OPTIMISMis the best medicine, when the world around is not as hopeful as they should be. This is the only way to challenge all kind of obstacles. Apart of it, following all health protocol as the pandemic has led to the adoption of particular hygienic behaviours (e.g., wearing masks, washing hands), which is important to save the world by minimizing the spread of covid-19 and other infectious disease (Varshini et al., 2020).

\section{REFERENCES}

Awareness of Polycystic Ovarian Disease among Females of Age Group 18-30 Years -ProQuest [cited 2020 Jun 7]. Available from: https://search.proquest.com/ openview/a8a09e7b2e9d2f96 7bf3fee479c7018a/1?pq- origsite $=$ gscholarCtcbl $=54977$

Brundha MP, Pathmashri VP, Sundari S. (2019). Quantitative Changes of Red Blood cells in Cancer Patients under Palliative Radiotherapy-A Retrospective Study. Vol. 12, Research Journal of Pharmacy and Technology. p. 687. Available from: http:// dx.doi. org/10.5958/0974-360x.2019.00122

Carey OJ, Cookson JB, Britton J, Tattersfield AE. (1996). The effect of lifestyle on wheeze, atopy, and bronchial hyperreactivity in Asian and white children. Vol. 154, American Journal of Respiratory and Critical Care Medicine. p. 537-40. Available from: http://dx.doi. org/10.1164/ajrccm.154.2.8756835

Lassale C., Batty G.D., Baghdadli A., Jacka F., SánchezVillegas A., Kivimäki M., Akbaraly T. (2019). Healthy dietary indices and risk of depressive outcomes: a systematic review and meta-analysis of observational studies. Mol. Psychiatry.;24:965-986. doi: 10.1038/ s41380-018-0237- 8

Ravichandran H, Brundha MP. (2016). Awareness about personal protective equipments in hospital workers (sweepers and cleaners). International Journal of Pharmaceutical Sciences Review and Research;40(1):28-9.

Shreya S, Brundha MP. (2017). Alteration of Haemoglobin Value in Relation to Age, Sex and Dental Diseases-A Retrospective Correlation Study . Vol. 10, Research Journal of Pharmacy and Technology. p. 1363. Available from: http://dx.doi. org/10.5958/0974360x.2017.00241.4

Samadarshi S.C.A., Sharma S., Bhatta J. (2020). An online survey of factors associated with self-perceived stress during the initial stage of the COVID-19 outbreak in Nepal. Ethiop. J. Health Dev;34(2):1-6.

Varshini A, Rani SL, Brundha MP. (2020). Awareness of annual doctor checkups among general population. Drug Invention Today;14(2).

Wood LG, Gibson PG. (2009). Dietary factors lead to innate immune activation in asthma. Vol. 123, Pharmacology \& Therapeutics.. p.37-53. Available from: http://dx.doi.org/10.1016/j. pharmthera. 03.015 